\title{
A 50-Year Personal Journey: Location, Gene Expression, and Circadian Rhythms
}

\author{
Michael Rosbash \\ Howard Hughes Medical Institute, National Center for Behavioral Genomics and Department of Biology, \\ Brandeis University, Waltham, Massachusetts 02454 \\ Correspondence: rosbash@brandeis.edu
}

I worked almost exclusively on nucleic acids and gene expression from the age of 19 as an undergraduate until the age of 38 as an associate professor. Mentors featured prominently in my choice of paths. My friendship with influential Brandeis colleagues then persuaded me that genetics was an important tool for studying gene expression, and I switched my experimental organism to yeast for this reason. Several years later, friendship also played a prominent role in my beginning work on circadian rhythms. As luck would have it, gene expression as well as genetics turned out to be important for circadian timekeeping. As a consequence, background and training put my laboratory in an excellent position to contribute to this aspect of the circadian problem. The moral of the story is, as in real estate, "location, location, location."

So how and why did I start working on circaSdian rhythms as a 38-year-old tenured professor at Brandeis in 1982? At that time, many senior figures in circadian biology were either trained in that discipline or in neuroscience. My path was very different. I graduated from Caltech in 1965 with a BS in Chemistry. There I worked on nucleic acids in the laboratories of Norman Davidson and then Robert Sinsheimer. Reg Kelly, who became a prominent cell biologist and neuroscientist at UCSF, was my mentor in the Sinsheimer laboratory. I then went for a year to Paris, where I recuperated from 4 years at Caltech and studied protein synthesis in the laboratory of Marianne Grunberg-Monago. Marianne had been a postdoc of Severo Ochoa at NYU, where she did the lion's share of the work for which Ochoa shared the 1959 Nobel
Prize with Arthur Kornberg (Grunberg-Manago et al. 1955). My mentor in that laboratory was her postdoc Cal McLaughlin, who later played a prominent role in yeast protein synthesis in collaboration with Jon Warner and Lee Hartwell. I then returned to the United States to attend graduate school at Massachusetts Institute of Technology (MIT). Although my $\mathrm{PhD}$ from there was officially in biophysics, I worked in the laboratory of Sheldon Penman; he was an ex-physicist turned cell physiologist with an intense interest in the messenger RNA (mRNA) of higher cells. The Watson and Crick epiphany in the mid-1950s had energized a community of people like Sheldon and his former mentor Jim Darnell to expand from gene expression studies of viruses and bacteria to RNA and protein synthesis of eukaryotes.

Editors: Paolo Sassone-Corsi, Michael W. Young, and Akhilesh B. Reddy

Additional Perspectives on Circadian Rhythms available at www.cshperspectives.org

Copyright (C) 2017 Cold Spring Harbor Laboratory Press; all rights reserved; doi: 10.1101/cshperspect.a032516

Cite this article as Cold Spring Harb Perspect Biol 2017;9:a032516 
M. Rosbash

I focused at MIT on membrane-bound protein synthesis in tissue culture cells and viruses, how ribosomes engage in the synthesis of secreted proteins and attach to the endoplasmic reticulum (Rosbash and Penman 1971a,b; Rosbash 1972). MIT was chock-full of interesting students and faculty, including Sheldon of course. He was also a first-rate advisor with an amazing cohort of students and postdocs, including Bob Weinberg and Rob Singer.

I then did a 3-year postdoc at the University of Edinburgh in the laboratory of John Bishop, who was a young faculty member in the Department of Epigenetics. This was at the time a modern spinoff from the Edinburgh Genetics Department, which was known for traditional quantitative genetics and was headed by Professor Douglas Falconer. Epigenetics was a term coined by the famous developmental biologist C.H. Waddington. Once it became clear that gene amplification and deletion was not the major mechanism by which different cells express different genes, in time or in space, "epigenetics" or differential gene expression must be the responsible mechanism. The term has obviously acquired a different meaning today. Wad, as he was known, had moved north from Cambridge, England to head this new department. My mentor Bishop was not only interested in eukaryotic gene expression like Penman but also in the development and application of nucleic acid-centric methods. I learned a great deal from John, who worked at that time with his own hands at the bench and was more of a biochemist than Penman (Bishop and Rosbash 1973, 1974; Bishop et al. 1974; Rosbash et al. 1974). In addition to John and his other trainees (e.g., Nick Hastie and Saveria Campo), Edinburgh was filled with interesting people and science, many of whom had a positive impact on my subsequent career. For example, Ed Southern of Southern blot fame was an MRC (Medical Research Council) young laboratory head in an adjacent building in Edinburgh. Ed was an inspiration both personally and professionally. Two other prominent people from that era are Adrian Bird and Michael Grunstein, who were both graduate students next door in Max Birnstiel's laboratory. Michael has become a lifelong close friend.
I arrived at Brandeis in the fall of 1974 as a newly minted assistant professor. I was 30 years old, and 9 years had passed since I graduated from Caltech. This was a standard trajectory in those days, when graduate work and postdocs were much shorter than they are today and almost no one strayed from the straight and narrow: a direct path from an undergraduate degree to graduate school, postdoctoral training, and then on to a faculty position. (My 1-year detour in Paris was highly unusual.) The Western world was in full postwar expansion, and no one worried about employment. We all assumed everything would work out, and it seemed like it did-for almost everyone. I received a birthday card from a close friend on my 30th birthday in Edinburgh. It said, "The world is your oyster." Indeed it was.

In this context ("the good old days"), it is notable that many prominent new professor instructors (PIs) had no publications during their postdocs, or their papers were published considerably after they took their first faculty jobs and often without the names of their postdoc mentors. This was true for my Brandeis friend and collaborator Jeff Hall, and it was also the case for his good pal Doug Kankel, who had a long career at Yale (Hall and Kankel 1976; Kankel and Hall 1976). Both Hall and Kankel were postdocs with Seymour Benzer at Caltech, and the work in these 1976 papers was substantially performed in the Benzer laboratory. It was also the case for other prominent trainees from this era. For example, Mike Young left the Hogness laboratory at Stanford and joined the faculty at Rockefeller without a first author publication that also carried Hogness' name. Although not true of everyone, the 1970 s were clearly a different era from this publication-CV point of view.

My plan at Brandeis was to continue the work I had been doing during my postdoc, to continue the study of gene expression changes during oogenesis and early development in Xenopus laevis (frog) oocytes and early embryos. I had begun this work in Edinburgh in collaboration with Peter Ford (Rosbash and Ford 1974; Ford et al. 1977). Peter was a postdoc in the neighboring laboratory of Max Birnstiel. 
(My postdoctoral advisor John Bishop was remarkably generous in letting me pursue whatever scientific problems interested me, in whatever collaborative arrangement I chose to make.) I started working on this problem as soon as I arrived at Brandeis in October of 1974 and had even written and submitted an NIH R01 grant on this topic before leaving the United Kingdom. Its funding began coincident with my arrival at Brandeis, which is another indication of how much more straightforward the practical aspects of scientific life were 40 years ago. My first students and postdocs worked on this topic, and the enterprise was quite successful. Nonetheless, my own restlessness and two external factors encouraged me to expand my horizons. (The restlessness could be more positively described as a function of my broad interests.)

The first factor was the advent of recombinant DNA technology. It had appeared in the literature during my postdoc. With great fanfare and not inconsiderable controversy, it progressed in just a few years from a concept, and then a technology for a select few, to an essential tool for much of the research community and pharmaceutical industry. Of contemporary interest perhaps, the current hoopla, promise, and publicity surrounding genome editing are not dissimilar from how recombinant DNA technology was received in the 1970s. That advance meant that one could study in detail specific individual genes and abandon the lessprecise study of collections of genes or RNA populations.

There was a local aspect to my embrace of recombinant DNA technology. Peter Wensink was hired at Brandeis as an assistant professor and had been trained in recombinant DNA technology during his postdoc in the Hogness laboratory at Stanford. Stanford was the mecca of this technology, where it had been invented and then put into practice. Peter's arrival at Brandeis coincided with mine, and his laboratory was also adjacent to mine in the open floor plan that was and still is the Rosenstiel Center for Basic Medical Sciences at Brandeis. Peter brought the required reagents and expertise with him from Stanford, which significantly
A 50-Year Personal Journey in Circadian Rhythms

lowered the energy barrier to my adopting this technology.

The second factor was my seduction by the "the awesome power of genetics." Contemporary practitioners now quite rightly view any study of gene expression as indistinguishable from genetics. (Genetics $=$ the study of genes $=$ the study of genomes = the study of gene expression.) However, this was not the case 40 years ago before the advent of recombinant DNA technology. Genetics was then more narrowly defined, for example, the study of chromosomes or meiosis, and it also referred to a strategy (i.e., using and making mutants to study a particular problem). I had been studying gene expression at MIT and then in Edinburgh, but I had no expertise or any serious interest in using genetics as a strategy (e.g., broadly mutagenizing a strain with little or no specificity, selecting for a phenotype, and characterizing the mutagenized strain and genes that underlie the phenotype).

Many people today refer to this aspect of genetics as "forward genetics." This term was coined to distinguish it from "reverse genetics," in which DNA sequences of specific genes can be deliberately mutated. As reverse genetics generally requires cloned and sequenced DNA and/or specific oligonucleotides to carry out the mutagenesis, it did not exist in the pre- or early recombinant DNA era. Then there was only forward genetics or its original term, genetics. Importantly, the organism and system I had been using in Scotland and then in my early years at Brandeis-frog oocytes and embryoswas opaque to genetic strategies.

My religious conversion to genetics began shortly after my arrival at Brandeis in the fall of 1974. It was because of my friendship with two evangelists, Jeff Hall and Lynna Hereford. Jeff had begun as a newly minted Brandeis assistant professor a few months before I arrived, and Lynna moved to my laboratory in the spring of 1975. Jeff and Lynna had both been trained as $\mathrm{PhD}$ students in the Department of Genetics at the University of Washington. This department was the first "genetics department" in the United States, with that word in its title. I imagined for some years after meeting Jeff and Lynna 
M. Rosbash

that the University of Washington Genetics Department conferred divinity as well as $\mathrm{PhD}$ degrees and then released these graduates to spread the genetics gospel around the country to life science Philistines like me.

To enable my learning about yeast and at the same time immerse Lynna in nucleic acid studies, we first collaborated to address general issues of yeast gene expression (e.g., how many protein-coding genes are encoded in the yeast genome). To these ends, Lynna and I used nucleic acid reassociation kinetics (Hereford and Rosbash 1977a,b), methods I had helped develop and used to study higher eukaryotic gene expression during my postdoc in Scotland (Bishop and Rosbash 1974; Bishop et al. 1974; Rosbash et al. 1974). We also used an aspect of reassociation kinetics to develop a method for cloning specific genes (Rosbash et al. 1979). It was used to clone histone genes (Hereford et al. 1979) as well as ribosomal protein genes (Woolford et al. 1979). Lynna went on to study the former, whereas I focused on the latter.

I had already been interested in ribosomal protein gene expression for some time when I began working on this problem in the late 1970s. There are about 80 of these proteins in eukaryotes (Ben-Shem et al. 2011). How do they get to be stoichiometric in the ribosome? (i.e., how is this regulation achieved?) There was an intriguing hint from the literature. John Warner and his colleagues had shown that a set of very interesting yeast temperaturesensitive mutants-dubbed at the time RNA mutants - had a selective effect on the synthesis of ribosomal proteins (Gorenstein and Warner 1976).

With our newly cloned ribosomal protein genes and the then just emerging northern blot technology, we could address what happened to the RNA profiles when the mutant yeast strains were shifted to the nonpermissive temperature. Although the mature ribosomal protein mRNA species rapidly disappeared as predicted, new higher molecular weight species appeared. They turned out to be introncontaining species, leading to several tentative conclusions (Rosbash et al. 1981). First, the regulation identified by the mutants indicated some form of posttranscriptional rather than transcriptional regulation. Second, the mutants probably affected pre-mRNA splicing and potentially identified a set of genes and proteins important for this recently discovered and then largely enigmatic process. Third, ribosomal protein genes must be enriched for intron-containing genes, which would explain the selectivity of the mutants for ribosomal protein synthesis. At that time, the actin gene was the only previously identified yeast gene to have an intron ( $\mathrm{Ng}$ and Abelson 1980).

All of these three predictions turned out to be correct. For reasons that are still uncertain, about $2 / 3$ of ribosomal protein genes contain introns, whereas only about $5 \%$ of total yeast genes contain introns (i.e., about 3\% of nonribosomal protein genes have introns) (Neuveglise et al. 2011); this accounts for the apparent specificity of the mutants for ribosomal protein synthesis. Most important, the RNA mutants, which were subsequently renamed PRP mutants for pre-mRNA processing mutants, turned out to be important entry points for identifying the splicing machinery and the detailed contributions of different splicing proteins and complexes to this complicated pathway. The RNA/PRP mutants were also my entree into the splicing problem, which I continued to study for more than 20 years after that initial paper (Rosbash et al. 1981).

The ability to subject mutant strains to a temperature shift and then examine events in vivo as a function of time after the shift proved remarkably rewarding. Equally important, the mutant strains proved invaluable when combined with in vitro splicing assays. Extracts could be used for mechanistic studies, which were difficult if not impossible in vivo. For example, extracts from strains that were deficient in specific proteins and steps could be assayed in vitro and used for reconstitution with recombinant proteins or protein complexes. Recognizing this possibility, John Abelson came to visit me at Brandeis in 1980 or 1981, shortly after he heard about our in vivo experiments. He and his close colleague Christine Guthrie became leaders in this field and trained many of the current senior people working in the yeast and splicing 
fields. My own trainees also became important contributors to these fields.

Shortly after establishing yeast as an important model for studying ribosomal protein gene expression, I wanted to examine ribosomal protein gene expression regulation in higher eukaryotes and decided to do this in Drosophila. To this end, we cloned the first ribosomal protein gene in metazoans, the Drosophila rp49 gene (Vaslet et al. 1980; O'Connell and Rosbash 1984); its mRNA is still a standard used in many Drosophila gene expression studies all over the world. This gene was also used to show that a minute mutation encodes a ribosomal protein (Kongsuwan et al. 1985). This study was the first link between this important set of Drosophila mutants and a gene product.

Although this work on rp49 bridged to the organism studied by my friend and colleague Jeff Hall, he had never been seriously interested in my work on nucleic acids or gene expression, whether in frogs, yeast, or flies. ("Seriously interested" means seriously thinking of working on the problem.) Nor had I been seriously interested in Drosophila courtship behavior and neuroscience, which his laboratory had been studying since his arrival at Brandeis. So our friendship remained just that: we had mutual interests in sports (including playing basketball for many years in a traditional noon pickup game at Brandeis), music, left-wing politics, and general scientific issues and gossip. Moreover, our pre-Brandeis backgrounds had multiple overlaps. I also came to know many of Jeff's pals from his time in Seymour's laboratory. They included Doug Kankel who went to Yale after Caltech as I mentioned above, Chip Quinn who went to Princeton, and Bill Harris. Doug and Chip were fellow postdocs, whereas Bill had been a Seymour graduate student and went to Harvard to do a postdoc. Jeff also got to know Ron Konopka at Caltech, who was finishing his $\mathrm{PhD}$ with Seymour when Jeff arrived. Jeff and Ron maintained a close relationship until Ron died in 2015. It was of course the landmark Konopka and Benzer paper published in 1971 that arguably initiated the Drosophila circadian field (Konopka and Benzer 1971). I use the word "arguably" to note the earlier Pittendrigh contributions on Drosophila pseudoobscura (Pittendrigh 1954; Pittendrigh 1966). The Konopka and Benzer paper also initiated my interest in the circadian field, as I often heard about it as well as stories about Ron from Jeff. However, there was no professional common ground that might have encouraged a collaboration between my laboratory and Jeff's. Several circumstances then came together at more or less the same time and changed the landscape.

First, Bambos Kyriacou, a postdoc in Jeff's laboratory, made an experimental bridge between Drosophila courtship and circadian rhythms. Bambos remains a terrific guy to this day, with a great sense of humor. He had discovered that the courtship song, what the male "sings" to the female by vibrating a wing, was affected by the Konopka period mutants (Kyriacou and Hall 1980). This paper showed that the song not only had a species-specific sound (frequency) but also a rhythm; the frequency was about $40 \mathrm{msec}$, and the rhythmic oscillations in frequency occurred with a period of about 1 min. Remarkably, that period was under control of the period mutants; for example, the short-period variant had a period of about $40 \mathrm{sec}$ and the long-period variant a period of about $80 \mathrm{sec}$. The key point here is not the courtship song but that circadian rhythms were being actively investigated in Jeff's laboratory. This heightened his interest in circadian biology beyond courtship as well as my own interest in the problem.

Second, recombinant DNA technology was making rapid progress. It became feasible by the early 1980 s to imagine cloning Drosophila period by "chromosome walking," a strategy pioneered by the Hogness laboratory at Stanford (Bender et al. 1983a,b; Spierer et al. 1983). Gene identification might then be performed by genetic rescue, which had just been accomplished by Rubin and Spradling (Rubin and Spradling 1982; Spradling and Rubin 1982). Although my laboratory was not engaged in these procedures, we were deep into other recombinant DNA studies as mentioned above. The gap was therefore not huge. I thus suggested to Jeff in the spring of 1982-after one of our basketball games-that we consider collaborating. 
M. Rosbash

The dream: cloning and sequencing might provide some insight into what period actually does and therefore how the circadian clock actually ticks. There was, however, still an energy barrier to overcome as well as new personnel required to begin this project.

Third, I was denied tenure in the Rosenstiel Center, where my laboratory was located in the 1970 s and early 1980s. Although this is a much longer story, the relevant part here is that my laboratory was forced to move to the only available Biology Department space, which was adjacent to Jeff's laboratory. It goes almost without saying that this proximity, including a shared conference room where we had joint laboratory meetings for many years, catalyzed our collaborative efforts.

Fourth, I had a serious health crisis in the summer of 1982. Suffice it to say that this crisis lowered the energy barrier to making serious changes to my life. They included deciding to work on the cloning of period as soon as someone appeared who was interested.

Fifth, a much more serious health crisis provided the required personnel and therefore the chance to begin the period cloning project. Vivian Ernst was a wonderful young Assistant Professor of Biochemistry at Brandeis, who tragically succumbed to breast cancer in early September of 1982. Her memorial service was my very first day back at work after those 6 weeks at home. I walked gingerly across campus to the chapel and then slowly and very sadly returned back to my laboratory. I was greeted there by a second-year graduate student of Vivian's, Pranitha Reddy. With tears in her eyes, she asked if she could do her thesis in my laboratory. I gave her the period cloning project, and this is how my collaborative work with Jeff Hall on circadian rhythms began in the early fall of 1982.

The first decade of published research from our laboratories, 1984-1994, is well documented in the literature and even described in many secondary sources. In my view, there is therefore little material to add. There are, however, a few personal anecdotes that might be of interest.

We were locked in an intense battle for primacy with the Young laboratory at Rockefeller for the first few years, and the cloning and rescue of period was performed independently in both places (Bargiello and Young 1984; Bargiello et al. 1984; Reddy et al. 1984; Zehring et al. 1984); Mike and his colleagues deserve high marks for their accomplishments. Although unpleasant, the competition contributed to a fast-paced focus, which probably contributed to some of our successes.

There were also some errors. In my opinion, our biggest one during these early years was a biochemistry paper suggesting that period encoded a proteoglycan (Reddy et al. 1986). The gene encoded an orphan protein in those early days of DNA sequencing; it contained no features of interest that could connect to proteins of known functions. Being desperate, we were seduced/hoodwinked by the only possible exception: glycine-threonine (GT) repeats within the period protein (Reddy et al. 1986). They connected to proteoglycans, which often have similar repeats within their sequences and are sites of $O$-linked glycosylation. If the fly period protein were a proteoglycan, it might have biochemical features consistent with this posttranslational modification (e.g., a high apparent molecular weight). Although I was more molecularly sophisticated than Jeff or anyone else in our groups, I was woefully deficient in biochemical expertise, meaning protein biochemistry. Taken together with the competition issue referred to above (the Young laboratory was also working on this proteoglycan hypothesis) and a lack of prudence, I was much too hasty in accepting and pushing forward our modest biochemical experiments. I still do not know whether those experiments were in error or just their interpretation; I suspect the results were correct but a result of protein aggregation. In any case, the proteoglycan hypothesis seemed to have legs at the time. Importantly, there was neither strong data to the contrary nor any competing hypotheses at that time.

That situation changed the following year with the publication of the protein sequence encoded by singleminded, a gene encoding a nuclear transcription factor. It had homology with the period protein (Crews et al. 1988). Although the homology was quite modest and could have 
reflected a motif shared by a large number of proteins with different functions, it offered an important competing hypothesis to proteoglycans: the period protein could be a transcription factor. This possibility coincided more or less with the first data from my postdoc Paul Hardin, indicating that the period mRNA underwent circadian oscillations in fly heads (Hardin et al. 1990). Paul gets full credit for making this important finding, including the important idea to use fly heads rather than whole bodies for the source of RNA. (The lack of cycling in certain body tissues reduces the cycling amplitude in whole flies to below credibility.) Importantly, the phase of RNA cycling was affected by the per missense mutations identically to their effects on behavioral phase, suggesting that the protein directly affected its own gene expression (Hardin et al. 1990). As the clock works upstream of behavior, this result might also reflect the influence of a clock operating upstream of gene expression. Circadian behavior might even be upstream of the gene expression regulation, and this possibility was included in the initial model figure (Fig. 5 in Hardin et al. 1990). Taken together with the homology to the single-minded transcription factor, however, the Hardin work suggested a more parsimonious hypothesis: the per protein was engaged in a negative feedback loop that affects its own expression and that this loop was "the clock" or at least central to timekeeping. The negative feedback loop would therefore also be upstream of the behavioral rhythms that are usually measured by circadian biologists.

Notably, Paul's success was helped by his local environment, the fact that a good fraction of his colleagues in my laboratory studied yeast RNA and were facile with state-of-the-art RNA methods. As polymerase chain reaction (PCR) did not exist at this time, Paul had to use RNase protection to assay-specific per mRNA levels. This method is not terribly difficult but also not trivial, so the Brandeis circadian work benefited from being adjacent to - in effect embedded within-a nucleic acid-centric research program.

This new working model of gene expression feedback was very attractive. It also seemed in- compatible with proteoglycans. I pushed hard to distinguish between the two possibilities. We had already shown that the GT region, the hallmark of the proteoglycan hypothesis, is not conserved nor is that region necessary for PER circadian function (Yu et al. 1987). Paul Hardin showed that feedback regulation depended on per $5^{\prime}$ flanking sequences (i.e., it predominantly reflected transcriptional regulation) (Hardin et al. 1992). Perhaps because it had been assumed that this was the case (there was not much appreciation at that time for posttranscriptional regulation), we had serious trouble publishing this important paper. These difficulties make for an interesting backstory, but I will save that for another time and place. A graduate student, Xin Liu, went to Seymour Benzer's laboratory to do immunoelectron microscopy and showed that PER was a nuclear protein (Liu et al. 1992). Last, another excellent graduate student Honkui Zeng then showed that PER overexpression led to low per RNA levels, consistent with negative feedback (Zeng et al. 1994).

The transcriptional feedback loop hypothesis was therefore quite robust by 1994 . Although I will not belabor the subsequent more than 20 years of work from all over the world and in many systems, their findings generally support this transcriptional feedback loop view of circadian rhythms in eukaryotes. There are, however, a few landmark accomplishments that deserve further mention.

There was the identification of the timeless gene by the Young laboratory in a forward genetic screen (Sehgal et al. 1994, 1995; Gekakis et al. 1995; Myers et al. 1995; Price et al. 1995). timeless was the second important clock gene, the first identified since the Konopka and Benzer paper. There was also the identification and cloning of the mammalian Clock by Takahashi and colleagues, also in a forward genetic screen (Vitaterna et al. 1994; Antoch et al. 1997; King et al. 1997), as well as their identification of its partner BMAL1 in collaboration with the Weitz laboratory (Gekakis et al. 1998). Ravi Allada and Joan Rutila spearheaded an effort in my laboratory to identify a positive transcription factor in the circadian system (Allada et al. 
M. Rosbash

1998; Rutila et al. 1998). The screen was successful and identified loss-of-function mutants in Drosophila Clock (protein $=$ CLK $=$ ortholog of mammalian Clock) and Cycle (protein = $\mathrm{CYC}=$ ortholog of BMAL1). The approach incorporated an interesting subscreen; the mutants were assayed for their effects on period transcription. We recovered many arrhythmic mutants, but only three showed little or no period transcription; two turned out to be alleles of $C Y C$ and the other an allele of CLK.

Patrick Emery and Ralf Stanewsky collaborated to clone fly cryptochrome (CRY) to show its importance for light regulation of the circadian clock and to identify and characterize a mutant loss-of-function strain of flies (Emery et al. 1998, 2001a,b; Stanewsky et al. 1998). Ironically, it is still not known how CRY actually works and how it collaborates with the eyes to perceive "circadian" light.

Circadian regulation is not only transcriptional (i.e., there are many important studies showing the importance of posttranscriptional regulation for circadian timekeeping). In my view, the original and key set of publications came from the Young laboratory, which identified the Drosophila doubletime gene. It encodes the kinase CKI, which is a crucial regulator of fly circadian period (Kloss et al. 1998; Price et al. 1998), and its ortholog plays an equally important role in mammals (Lowrey et al. 2000). Notably, PER appears to be a very important circadian substrate (Ko et al. 2002), which can be interpreted to reinforce the centrality of the transcriptional feedback loop.

Although this story focuses on animal clocks and especially on flies, a robust and biologically relevant transcription-translation circadian clock functions in plants (Nohales and Kay 2016). In addition, there is a quite different circadian clock in a prokaryotic photosynthetic organism, namely cyanobacteria. This clock in its simplest form requires three genes: $k a i A$, $k a i B$, and $k a i C$ (Ishiura et al. 1998). It is also of adaptive significance (i.e., the clock contributes to fitness) (Ouyang et al. 1998). A landmark biochemical study from Kondo and colleagues showed that the circadian clock could be reconstructed in vitro with three recombinant pro- teins (Kai A, B, and C) and ATP (Nakajima et al. 2005). It therefore can function without transcription, and this simple in vitro clock is even temperature-compensated (i.e., the circadian period is essentially temperature-invariant). This work was elegant and compelling beyond words (in a word, "breathtaking").

Notably, there is still no bona fide parallel to the Kai system in the eukaryotic world, even after more than 15 years of having these protein sequences and now substantial mechanistic information on the cyanobacterial clock. It therefore remains likely that the cyanobacterial and eukaryotic systems arose independently (i.e., circadian clocks appeared multiple times in evolution (Rosbash 2009). Moreover, bona fide and well-characterized circadian clocks have not been reported outside of cyanobacteria (Ma et al. 2016). This is despite the fact that the three different Kai genes are found distributed among archaeal and protobacterial species as well as all cyanobacterial species (Dvornyk et al. 2003) and the fact that the cyanobacterial clock can be transplanted to Escherichia coli (Chen et al. 2015). Some cyanobacterial species even solve the sensitivity of nitrogen fixation to oxygen problem with spatial rather than temporal segregation (Ernst et al. 1992). An implication of this prokaryotic digression is that eukaryotic transcription-translation clocks may have had broader phylogenetic impact than the cyanobacterial clock.

A more recent challenge to the PER-CLK transcription-centric animal model is the proposed role of metabolism and specifically peroxiredoxin hyperoxidation in circadian rhythms. A set of crucial experiments shows that these rhythms are independent of transcriptional rhythms in human red blood cells as well as in fly and mouse systems (O’Neill and Reddy 2011; O'Neill et al. 2011; Edgar et al. 2012). Importantly, key aspects of the red blood cell experiments were independently replicated (Cho et al. 2014). As mammalian red blood cells lack nuclei and therefore transcription, aspects of this very important hypothesis are likely to be correct. However, very specialized conditions were necessary to repeat the in vitro peroxiredoxin cycling, explaining perhaps why there was 
no peroxiredoxin cycling observed in red blood cells taken directly from animals in this study (Cho et al. 2014). Importantly, no laboratory has independently replicated the experiments showing the cycling of hyperoxidized peroxiredoxin in flies and mice bearing arrhythmic mutations in key clock proteins (Edgar et al. 2012). These stunning results suggested that these rhythms truly run independently from the core clock transcriptional machinery. Although animal metabolic rhythms are expected, their complete independence from the core clock machinery and the downstream behavioral rhythms is surprising and therefore very important if true, hence, the desire for replication. For example, sleep-wake as well as food-consumption rhythms are under clock control in ad lib-fed animals, and one imagines that metabolic rhythms might predominantly follow food ingestion. A key experiment to distinguish between the possibilities has not been performed in my view; metabolic and peroxiredoxin rhythms should be assessed in fast and slow running circadian mutants in constant darkness. Are the peroxiredoxin rhythms truly independent or are they influenced by the core clock transcriptional machinery?

Another fly in the ointment is/was the male courtship song rhythm (Kyriacou and Hall 1980). How can transcriptional feedback accommodate a rhythm with a 1 min period? Perhaps the courtship song rhythm really does reflect another function of PER, which does not involve transcription. Although this view of the courtship song rhythm is not without controversy (Stern 2014), the story is ongoing (Kyriacou et al. 2017).

There are other big-picture questions that still remain unanswered. What fraction of the genome is really controlled by the clock? As the current estimate is at least 50\% (Zhang et al. 2014), might it be $100 \%$ (i.e., might every gene be controlled by the circadian clock somewhere)?

Work in the mammalian system indicates that many or most, perhaps even all, cells and tissue contain a canonical circadian clock (Balsalobre et al. 1998; Zhang et al. 2014). Yet there may be important exceptions, and the brain is a tissue that is not well explored from this point of view. In the fly, only a small number of neurons, about 75 pairs of cells bilaterally located in the central brain, contain a functional clock by immunohistochemical criteria (i.e., staining for clock proteins) (Tataroglu and Emery 2014). Most fly neurons may therefore be "clockless," of which a specific example is the dopaminergic system. Most of these neurons seem to be missing clock gene expression (Abruzzi et al. 2017); mammalian dopaminergic neurons also may not express clock gene transcripts (S Nelson, pers. comm.). Single-cell sequencing should eventually address the general question about brain neurons and circadian clocks in mammals as well as flies.

Looking toward the future, eukaryotic systems in my opinion are still in search of satisfactory and general explanations for temperature compensation, notwithstanding the publication of some elegant studies that have addressed this problem (Mehra et al. 2009). As mentioned above, this mechanistic term refers to the fact that circadian period is essentially temperature-invariant. I might add in this context that we also do not know the rate-limiting step or steps that govern circadian timekeeping. In other words, what determines the pace of the clock? Is there only one rate-limiting step or are there more than one, each governing a discrete portion of the cycle. Mutants are an unreliable guide to defining the pacesetters or rate-limiting steps in normal (wild-type) animals (Rosbash 2009). I suspect that these two problems, rate-limiting steps and temperature compensation, are related; every rate-limiting step should be temperature-compensated. This prediction assumes that there is no compensation at some gross level, for example, that the transcription and accumulation of PER and TIM accelerate, whereas their subsequent protein turnover slows down at elevated temperatures. Surprisingly, this has never been tested to my knowledge.

The fly has also become an attractive model for sleep studies. This is a result of pioneering studies by two groups more than 15 years ago (Hendricks et al. 2000; Shaw et al. 2000). The purpose of sleep as well as its regulation is one of 
M. Rosbash

the great mysteries of neuroscience, indeed of biology writ large. Classical studies in mammals indicate that sleep is regulated by the circadian system as well as by a much more mysterious homeostatic regulatory system (Borbely 1982; Daan et al. 1984; Borbely et al. 2016). The former reflects the internal timekeeper that generates our regular daily changes in sleepiness and alertness, whereas the latter keeps track of sleep need and responds to external events like sleep deprivation. We have recently shown that specific circadian neurons in the fly brain promote sleep by inhibiting other wake-promoting circadian neurons, and that this interplay between circadian neurons is a major feature of the circadian regulation of sleep (Guo et al. 2016). Although these studies do not impact on homeostatic regulation, the fly is also beginning to illuminate the principles that underlie this mysterious process (e.g., Donlea et al. 2014). As we originally learned from developmental biological studies and then from circadian biology, the fly may once again provide insights that will illuminate the mammalian landscape, in this case for the function and regulation of sleep. And to finish more or less where I began, it will not surprise me if gene expression regulation is a prominent feature of sleep regulation.

\section{REFERENCES}

Abruzzi KC, Zadina A, Luo W, Wiyanto E, Rahman R, Guo F, Shafer O, Rosbash M. 2017. RNA-seq analysis of Drosophila clock and non-clock neurons reveals neuronspecific cycling and novel candidate neuropeptides. PLoS Genet 13: e1006613.

Allada R, White NE, So WV, Hall JC, Rosbash M. 1998. A mutant Drosophila homolog of mammalian Clock disrupts circadian rhythms and transcription of period and timeless. Cell 93: 791-804.

Antoch MP, Song EJ, Chang AM, Vitaterna MH, Zhao Y, Wilsbacher LD, Sangoram AM, King DP, Pinto LH, Takahashi JS. 1997. Functional identification of the mouse circadian clock gene by transgenic BAC rescue. Cell 89: 655-667.

Balsalobre A, Damiola F, Schibler U. 1998. Immortalized rat fibroblasts contain a circadian clock. Cell 93: 929-937.

Bargiello TA, Young MW. 1984. Molecular genetics of a biological clock in Drosophila. Proc Natl Acad Sci 81: 2142-2146.

Bargiello TA, Jackson FR, Young MW. 1984. Restoration of circadian behavioural rhythms by gene transfer in Drosophila. Nature 312: 752-754.
Ben-Shem A, Garreau de Loubresse N, Melnikov S, Jenner L, Yusupova G, Yusupov M. 2011. The structure of the eukaryotic ribosome at $3.0 \AA$ resolution. Science 334: 1524-1529.

Bender W, Akam M, Karch F, Beachy PA, Peifer M, Spierer P, Lewis EB, Hogness DS. 1983a. Molecular genetics of the bithorax complex in Drosophila melanogaster. Science 221: 23-29.

Bender W, Spierer P, Hogness DS. 1983b. Chromosomal walking and jumping to isolate DNA from the Ace and rosy loci and the bithorax complex in Drosophila melanogaster. J Mol Biol 168: 17-33.

Bishop JO, Rosbash M. 1973. Reiteration frequency of duck haemoglobin genes. Nat New Biol 241: 204-207.

Bishop JO, Rosbash M. 1974. Polynucleotide sequences in eukaryotic DNA and RNA that form ribonucleaseresistant complexes with polyuridylic acid. J Mol Biol 85: $75-86$.

Bishop JO, Morton JG, Rosbash M, Richardson M. 1974. Three abundance classes in HeLa cell messenger RNA. Nature 250: 199-204.

Borbely AA. 1982. A two process model of sleep regulation. Hum Neurobiol 1: 195-204.

Borbely AA, Daan S, Wirz-Justice A, Deboer T. 2016. The two-process model of sleep regulation: A reappraisal. $J$ Sleep Res 25: 131-143.

Chen AH, Lubkowicz D, Yeong V, Chang RL, Silver PA. 2015. Transplantability of a circadian clock to a noncircadian organism. Sci Adv 1: e1500358.

Cho CS, Yoon HJ, Kim JY, Woo HA, Rhee SG. 2014. Circadian rhythm of hyperoxidized peroxiredoxin II is determined by hemoglobin autoxidation and the 20S proteasome in red blood cells. Proc Natl Acad Sci 111: 12043-12048.

Crews ST, Thomas JB, Goodman CS. 1988. The Drosophila single-minded gene encodes a nuclear protein with sequence similarity to the per gene product. Cell 52: $143-$ 152.

Daan S, Beersma DG, Borbely AA. 1984. Timing of human sleep: Recovery process gated by a circadian pacemaker. Am J Physiol 246: R161-R183.

Donlea JM, Pimentel D, Miesenbock G. 2014. Neuronal machinery of sleep homeostasis in Drosophila. Neuron 81: 860-872.

Dvornyk V, Vinogradova O, Nevo E. 2003. Origin and evolution of circadian clock genes in prokaryotes. Proc Natl Acad Sci 100: 2495-2500.

Edgar RS, Green EW, Zhao Y, van Ooijen G, Olmedo M, Qin X, Xu Y, Pan M, Valekunja UK, Feeney KA, et al. 2012. Peroxiredoxins are conserved markers of circadian rhythms. Nature 485: 459-464.

Emery P, So WV, Kaneko M, Hall JC, Rosbash M. 1998. CRY, a Drosophila clock and light-regulated cryptochrome, is a major contributor to circadian rhythm resetting and photosensitivity. Cell 95: 669-679.

Emery P, Stanewsky R, Hall JC, Rosbash M. 2000a. A unique circadian-rhythm photoreceptor. Nature 404: 456-457.

Emery P, Stanewsky R, Helfrich-Förster C, Emery-Le M, Hall JC, Rosbash M. 2000b. Drosophila CRY is a deep brain circadian photoreceptor. Neuron 26: 493-504. 
Ernst A, Black T, Cai Y, Panoff JM, Tiwari DN, Wolk CP 1992. Synthesis of nitrogenase in mutants of the cyanobacterium Anabaena sp. strain PCC 7120 affected in heterocyst development or metabolism. J Bacteriol 174: 6025-6032.

Ford PJ, Mattieson T, Rosbash M. 1977. Very long-lived messenger RNA in ovaries of Xenopus laevis. Dev Biol 57: 417-426.

Gekakis N, Saez L, Delahaye-Brown A-M, Myers MP, Sehgal A, Young MW, Weitz CJ. 1995. Isolation of timeless by PER protein interactions: Defective interaction between timeless protein and long-period mutant $\mathrm{PER}^{\mathrm{L}}$. Science 270: $811-815$.

Gekakis N, Staknis D, Nguyen HB, Davis CF, Wilsbacher LD, King DP, Takahashi JS, Weitz CJ. 1998. Role of the CLOCK protein in the mammalian circadian mechanism. Science 280: $1564-1569$.

Gorenstein C, Warner JR. 1976. Coordinate regulation of the synthesis of eukaryotic ribosomal proteins. Proc Natl Acad Sci 73: 1547.

Grunberg-Manago M, Oritz PJ, Ochoa S. 1955. Enzymatic synthesis of nucleic acidlike polynucleotides. Science 122: 907-910.

Guo F, Yu J, Jung HJ, Abruzzi KC, Luo W, Griffith LC, Rosbash M. 2016. Circadian neuron feedback controls the Drosophila sleep-activity profile. Nature 536: 292-297.

Hall JC, Kankel DR. 1976. Genetics of acetylcholinesterase in Drosophila melanogaster. Genetics 83: 517-535.

Hardin PE, Hall JC, Rosbash M. 1990. Feedback of the Drosophila period gene product on circadian cycling of its messenger RNA levels. Nature 343: 536-540.

Hardin PE, Hall JC, Rosbash M. 1992. Circadian oscillations in period gene mRNA levels are transcriptionally regulated. Proc Natl Acad Sci 89: 11711-11715.

Hendricks JC, Finn SM, Panckeri KA, Chavkin J, Williams JA, Sehgal A, Pack AI. 2000. Rest in Drosophila is a sleeplike state. Neuron 25: 129-138.

Hereford LM, Rosbash M. 1977a. Number and distribution of polyadenylated RNA sequences in yeast. Cell 10: $453-$ 462 .

Hereford LM, Rosbash M. 1977b. Regulation of a set of abundant mRNA sequences. Cell 10: 463-467.

Hereford L, Fahrner K, Woolford JLJ, Rosbash M, Kaback DB. 1979. Isolation of yeast histone genes H2A and H2B. Cell 18: 1261-1271.

Ishiura M, Kutsuna S, Aoki S, Iwasaki H, Andersson CR, Tanabe A, Golden SS, Johnson CH, Kondo T. 1998. Expression of a gene cluster kaiABC as a circadian feedback process in cyanobacteria. Science 281: 1519-1523.

Kankel DR, Hall JC. 1976. Fate mapping of nervous system and other internal tissues in genetic mosaics of Drosophila melanogaster. Dev Biol 48: 1-24.

King DP, Zhao Y, Sangoram AM, Wilsbacher LD, Tanaka M, Antoch MP, Steeves TDL, Vitaterna MH, Kornhauser JM, Lowrey PL, et al. 1997. Positional cloning of the mouse circadian clock gene. Cell 89: 641-653.

Kloss B, Price JL, Saez L, Blau J, Rothenfluh A, Wesley CS, Young MW. 1998. The Drosophila clock gene double-time encodes a protein closely related to human casein kinase IE. Cell 94: 97-107.
A 50-Year Personal Journey in Circadian Rhythms

Ko HW, Jiang J, Edery I. 2002. Role for Slimb in the degradation of Drosophila Period protein phosphorylated by Doubletime. Nature 420: 673-678.

Kongsuwan K, Yu Q, Vincent A, Frisardi MC, Rosbash M, Lengyel JA, Merriam J. 1985. A Drosophila Minute gene encodes a ribosomal protein. Nature 317: 555-558.

Konopka RJ, Benzer S. 1971. Clock mutants of Drosophila melanogaster. Proc Natl Acad Sci 68: 2112-2116.

Kyriacou CP, Hall JC. 1980. Circadian rhythm mutations in Drosophila melanogaster affect short-term fluctuations in the male's courtship song. Proc Natl Acad Sci 77: 67296733.

Kyriacou CP, Green EW, Piffer A, Dowse HB. 2017. Failure to reproduce period-dependent song cycles in Drosophila is due to poor automated pulse-detection and low-intensity courtship. Proc Natl Acad Sci 114: 1970-1975.

Liu X, Zwiebel LJ, Hinton D, Benzer S, Hall JC, Rosbash M. 1992. The period gene encodes a predominantly nuclear protein in adult Drosophila. J Neurosci 12: 2735-2744.

Lowrey PL, Shimomura K, Antoch MP, Yamazaki S, Zemenides PD, Ralph MR, Menaker M, Takahashi JS. 2000. Positional syntenic cloning and functional characterization of the mammalian circadian mutation tau. Science 288: $483-492$.

Ma P, Mori T, Zhao C, Thiel T, Johnson CH. 2016. Evolution of KaiC-dependent timekeepers: A proto-circadian timing mechanism confers adaptive fitness in the purple bacterium Rhodopseudomonas palustris. PLoS Genet 12: e1005922.

Mehra A, Shi M, Baker CL, Colot HV, Loros JJ, Dunlap JC. 2009. A role for casein kinase 2 in the mechanism underlying circadian temperature compensation. Cell 137: 749-760.

Myers MP, Wager-Smith K, Wesley CS, Young MW, Sehgal A. 1995. Positional cloning and sequence analysis of the Drosophila clock gene timeless. Science 270: 805-808.

Nakajima $\mathrm{M}$, Imai $\mathrm{K}$, Ito $\mathrm{H}$, Nishiwaki T, Murayama $\mathrm{Y}$, Iwasaki H, Oyama T, Kondo T. 2005. Reconstitution of circadian oscillation of cyanobacterial KaiC phosphorylation in vitro. Science 308: 414-415.

Neuveglise C, Marck C, Gaillardin C. 2011. The intronome of budding yeasts. $C$ R Biol 334: 662-670.

$\mathrm{Ng} \mathrm{R}$, Abelson J. 1980. Isolation and sequence of the gene for actin in Saccharomyces cerevisiae. Proc Natl Acad Sci 77: 3912-3916.

Nohales MA, Kay SA. 2016. Molecular mechanisms at the core of the plant circadian oscillator. Nat Struct Mol Biol 23: 1061-1069.

O'Connell P, Rosbash M. 1984. Sequence, structure, and codon preference of the Drosophila ribosomal protein 49 gene. Nucl Acids Res 12: 5495-5513.

O’Neill JS, Reddy AB. 2011. Circadian clocks in human red blood cells. Nature 469: 498-503.

O’Neill JS, van Ooijen G, Dixon LE, Troein C, Corellou F, Bouget FY, Reddy AB, Millar AJ. 2011. Circadian rhythms persist without transcription in a eukaryote. Nature 469: 554-558.

Ouyang Y, Andersson CR, Kondo T, Golden SS, Johnson CH. 1998. Resonating circadian clocks enhance fitness in cyanobacteria. Proc Natl Acad Sci 95: 8660-8664. 
M. Rosbash

Pittendrigh CS. 1954. On temperature independence in the clock-system controlling emergence time in Drosophila. Proc Natl Acad Sci 40: 1018-1029.

Pittendrigh CS. 1966. The circadian oscillation in Drosophila subobscura pupae: A model for the photoperiodic clock. Z Pflanzenphysiol 54: 275-307.

Price JL, Dembinska ME, Young MW, Rosbash M. 1995. Suppression of PERIOD protein abundance and circadian cycling by the Drosophila clock mutation timeless. EMBO J 14: 4044-4049.

Price JL, Blau J, Rothenfluh A, Abodeely M, Kloss B, Young MW. 1998. double-time is a novel Drosophila clock gene that regulates PERIOD protein accumulation. Cell 94: 83-95.

Reddy P, Zehring WA, Wheeler DA, Pirrotta V, Hadfield C, Hall JC, Rosbash M. 1984. Molecular analysis of the period locus in Drosophila melanogaster and identification of a transcript involved in biological rhythms. Cell 38: 701-710.

Reddy P, Jacquier AC, Abovich N, Petersen G, Rosbash M. 1986. The period clock locus of D. melanogaster codes for a proteoglycan. Cell 46: 53-61.

Rosbash M. 1972. Formation of membrane-bound polyribosomes. J Mol Biol 65: 413-422.

Rosbash M. 2009. The implications of multiple circadian clock origins. PLoS Biol 7: e62.

Rosbash M, Ford PJ. 1974. Polyadenylic acid-containing RNA in Xenopus laevis oocytes. J Mol Biol 85: 87-101.

Rosbash M, Penman S. 1971a. Membrane-associated protein synthesis of mammalian cells. I: The two classes of membrane-associated ribosomes. J Mol Biol 59: 227241.

Rosbash M, Penman S. 1971b. Membrane-associated protein synthesis of mammalian cells. II: Isopycnic separation of membrane-bound polyribosomes. J Mol Biol 59: 243-253.

Rosbash M, Ford PJ, Bishop JO. 1974. Analysis of the C-value paradox by molecular hybridization. Proc Natl Acad Sci 71: 3746-3750.

Rosbash M, Blank D, Fahrner K, Hereford L, Riccardi R, Roberts B, Ruby S, Woolford JL Jr. 1979. R-looping and structural gene identification of recombinant DNA. Methods Enzymol 68: 454-469.

Rosbash M, Harris PKW, Woolford JL Jr, Teem JL. 1981. The effect of temperature-sensitive RNA mutants on the transcription products from cloned ribosomal protein genes of yeast. Cell 24: 679-686.

Rubin GM, Spradling AC. 1982. Genetic transformation of Drosophila with transposable element vectors. Science 218: 348-353.

Rutila JE, Suri V, Le M, So WV, Rosbash M, Hall JC. 1998. CYCLE is a second bHLH-PAS clock protein essential for circadian rhythmicity and transcription of Drosophila period and timeless. Cell 93: 805-814.

Sehgal A, Price J, Man B, Young M. 1994. Loss of circadian behavioral rhythms and per RNA oscillations in the Drosophila mutant timeless. Science 263: 1603-1606.

Sehgal A, Rothenfluh-Hilfiker A, Hunter-Ensor M, Chen Y, Myers M, Young MW. 1995. Rhythmic expression of timeless: A basis for promoting circadian cycles in period gene autoregulation. Science 270: 808-810.

Shaw PJ, Cirelli C, Greenspan RJ, Tononi G. 2000. Correlates of sleep and waking in Drosophila melanogaster. Science 287: $1834-1837$.

Spierer P, Spierer A, Bender W, Hogness DS. 1983. Molecular mapping of genetic and chromomeric units in Drosophila melanogaster. J Mol Biol 168: 35-50.

Spradling AC, Rubin GM. 1982. Transposition of cloned P elements into Drosophila germ line chromosomes. Science 218: 341-347.

Stanewsky R, Kaneko M, Emery P, Beretta M, Wager-Smith K, Kay SA, Rosbash M, Hall JC. 1998. The cryb mutation identifies cryptochrome as a circadian photoreceptor in Drosophila. Cell 95: 681-692.

Stern DL. 2014. Reported Drosophila courtship song rhythms are artifacts of data analysis. BMC Biol 12: 38 .

Tataroglu O, Emery P. 2014. Studying circadian rhythms in Drosophila melanogaster. Methods 68: 140-150.

Vaslet CA, O'Connell P, Izquierdo M, Rosbash M. 1980. Isolation and mapping of a cloned ribosomal protein gene of Drosophila melanogaster. Nature 285: 674-676.

Vitaterna MH, King DP, Chang AM, Kornhauser JM, Lowrey PL, McDonald JD, Dove WF, Pinto LH, Turek FW, Takahashi JS. 1994. Mutagenesis and mapping of a mouse gene, Clock, essential for circadian behavior. Science 264: 719-725.

Woolford JL Jr, Hereford LM, Rosbash M. 1979. Isolation of cloned DNA sequences containing ribosomal protein genes from Saccharomyces cerevisiae. Cell 18: 1247-1259.

Yu Q, Colot HV, Kyriacou CP, Hall JC, Rosbash M. 1987. Behaviour modification by in vitro mutagenesis of a variable region within the period gene of Drosophila. Nature 326: $765-769$.

Zehring WA, Wheeler DA, Reddy P, Konopka RJ, Kyriacou CP, Rosbash M, Hall JC. 1984. P-element transformation with period locus DNA restores rhythmicity to mutant, arrhythmic Drosophila melanogaster. Cell 39: 369-376.

Zeng H, Hardin PE, Rosbash M. 1994. Constitutive overexpression of the Drosophila period protein inhibits period mRNA cycling. EMBO J 13: 3590-3598.

Zhang R, Lahens NF, Ballance HI, Hughes ME, Hogenesch JB. 2014. A circadian gene expression atlas in mammals: Implications for biology and medicine. Proc Natl Acad Sci 111: $16219-16224$. 


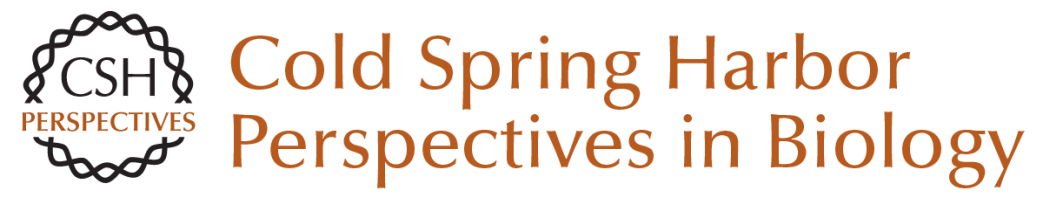

\title{
A 50-Year Personal Journey: Location, Gene Expression, and Circadian Rhythms
}

\author{
Michael Rosbash
}

Cold Spring Harb Perspect Biol 2017; doi: 10.1101/cshperspect.a032516 originally published online June 9, 2017

\section{Subject Collection Circadian Rhythms}

\section{Circadian Posttranscriptional Regulatory \\ Mechanisms in Mammals \\ Carla B. Green}

Design Principles of Phosphorylation-Dependent

Timekeeping in Eukaryotic Circadian Clocks

Koji L. Ode and Hiroki R. Ueda

Interplay between Microbes and the Circadian

Clock

Paola Tognini, Mari Murakami and Paolo Sassone-Corsi

A 50-Year Personal Journey: Location, Gene

Expression, and Circadian Rhythms Michael Rosbash

Regulating the Suprachiasmatic Nucleus (SCN)

Circadian Clockwork: Interplay between

Cell-Autonomous and Circuit-Level Mechanisms Erik D. Herzog, Tracey Hermanstyne, Nicola J. Smyllie, et al.

Systems Chronobiology: Global Analysis of Gene Regulation in a 24-Hour Periodic World Jérôme Mermet, Jake Yeung and Felix Naef
Coordination between Differentially Regulated

Circadian Clocks Generates Rhythmic Behavior Deniz Top and Michael W. Young

Introduction to Chronobiology Sandra J. Kuhlman, L. Michon Craig and Jeanne F. Duffy

Cellular Timekeeping: It's Redox o'Clock Nikolay B. Milev, Sue-Goo Rhee and Akhilesh B. Reddy

Molecular Mechanisms of Sleep Homeostasis in Flies and Mammals

Ravi Allada, Chiara Cirelli and Amita Sehgal

Membrane Currents, Gene Expression, and Circadian Clocks

Charles N. Allen, Michael N. Nitabach and Christopher S. Colwell

The Plant Circadian Clock: From a Simple Timekeeper to a Complex Developmental Manager Sabrina E. Sanchez and Steve A. Kay

For additional articles in this collection, see http://cshperspectives.cshlp.org/cgi/collection/

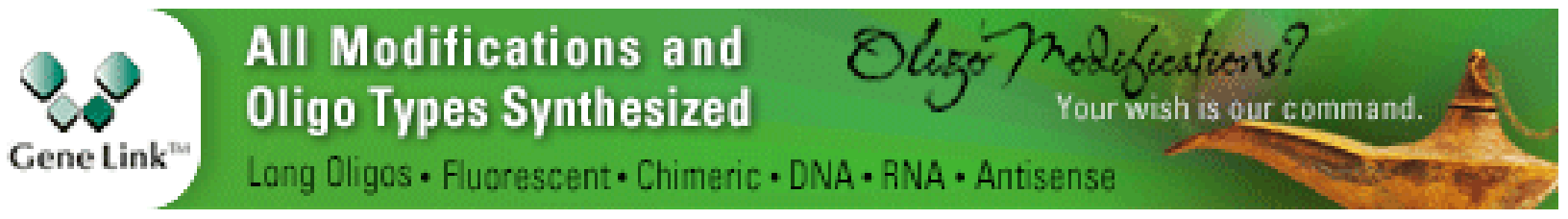

